\title{
The potassium channel gene HK1 maps to human chromosome 11p14.1, close to the FSHB gene
}

\author{
Manfred Gessler ${ }^{1}$, Andrew Grupe ${ }^{2}$, Karl-Heinz Grzeschik ${ }^{1}$, Olaf Pongs ${ }^{2}$ \\ ${ }^{\mathrm{I}}$ Institut für Humangenetik, Philipps Universităt, Bahnhofstrasse 7A, W-3550 Marburg, Federal Republic of Germany \\ ${ }^{2}$ Zentrum für molekulare Neurobiologie, Uniklinikum Eppendorf, Martinistrasse 52, W-2000 Hamburg 20, Federal Republic of Germany
}

Received: 23 April 1992 / Revised: 24 June 1992

\begin{abstract}
Transiently activating (A-type) potassium (K) channels are important regulators of action potential and action potential firing frequencies. HK1 designates the first human CDNA that is highly homologous to the rat RCK4 cDNA that codes for an A-type K-channel. The HK1 channel is expressed in heart. By somatic cell hybrid analysis, the HK1 gene has been assigned to human chromosome 11p13-p14, the WAGR deletion region (Wilms tumor, aniridia, genito-urinary abnormalities and mental retardation). Subsequent pulsed field gel (PFG) analysis and comparison with the well-established PFG map of this region localized the gene to $11 \mathrm{p} 14,200-$ $600 \mathrm{~kb}$ telomeric to the FSHB gene.
\end{abstract}

\section{Introduction}

Potassium (K) channels are highly diverse membrane proteins that seem to be present in nearly every eukaryotic cell (Hille 1984). The rat genome encodes a K-channel family (RCK) homologous to the Drosophila Shaker channels (Stuehmer et al. 1989). To date, only one member of this RCK family (RCK4) has been detected that expresses A-type (rapidly inactivating) K-channels.

Recently a full lenght human CDNA (HK1) has been cloned; it encodes a K-channel protein highly homologous to RCK4 (97\% identity; Tamkun et al. 1991). HK1 mRNA is expressed in heart, in particular in the atrium and ventricle. Therefore, the $\mathrm{K}$-channel formed by this protein might be important in the regulation of the fast repolarizing phase of action potentials in heart and thus might influence cardiac action potential duration (Josephson et al. 1984).

To further the genetic characterization of the human HK1 gene, we have determined the precise chromosomal localization of this gene. Using the polymerase chain reaction (PCR), we have produced a genomic HK1 DNA probe to map the HK1 gene on human chro-

Correspondence to: M. Gessler mosome $11 \mathrm{p} 14$ by somatic cell hybrid and pulsed field gel analysis (PFGE).

\section{Materials and methods}

\section{DNA probes}

Two degenerated primers, backtranslated from the RCK4 protein (aa: 170-178, 406-414, Stuehmer et al. 1989) were used to amplify human RCK4 anologous DNA. The upstream and downstream primers were 5'-TCAGATCGATACAGNGA(C/T)TG(T/C)TG(T/C)GAA-3' and 5'-AATGAATTC(G/T/A)AT(A/T/C)TCA(A/G/A)TG(A/G/A)TG(T/A)TCAT-3'. The primers contain ClaI and EcoRI restriction sites for subcloning. Human HeLa cell DNA was used as a template for amplification (Grupe et al. 1990). The PCR reaction was performed in a Perkin Elmer/Cetus Thermocycler for 30 cycles: $60 \mathrm{~s}$ at $92^{\circ} \mathrm{C}, 30 \mathrm{~s}$ at $40^{\circ} \mathrm{C}$ and $90 \mathrm{~s}$ at $72^{\circ} \mathrm{C}$. The amplified DNA-fragment was digested with $C l a \mathrm{~V} / E c o \mathrm{RI}$ and subcloned into Bluescript KS+ (Stratagene). The subcloned DNAfragment, pHK4, was sequenced according to the method of Sanger et al. (1977).

Probe p202 is a $2.7-\mathrm{kb}$ HindIII single copy segment from clone L202-1 that has been mapped to human chromosome 11 p14 (Gessler et al. 1989a,b). The 500-bp HincII/SacI fragment of pRS1.2 (Watkins et al. 1987) was used as a probe for FSHB.

\section{Somatic cell hybrid analysis}

The chromosomal complement of the somatic cell hybrid panel used in this study has been described elsewhere (Willecke et al. 1990). The J1 derived hybrids were obtained from Dr. C. Jones, ERCI, Denver (Glaser et al. 1990). The WAGR (Wilms tumor, amiridia, genito-urinary abnormalities and mental retardation) deletion hybrids cell lines were provided by Dr. G. Bruns, Children's Hospital, Boston (Gessler et al. 1989a). DNA preparation, restriction enzyme digestion, agarose gel electrophoresis and Southern blotting were performed according to standard protocols (Sambrook et al. 1989). Probes were labelled by oligonucleotide priming (Feinberg and Vogelstein 1984) and hybridized as described in Gessler et al. (1989a). Autoradiographic exposure times were 1-3 days at $-70^{\circ} \mathrm{C}$.

\section{PFGE analysis}

The lymphoblastoid cell line 6697 , which formed the basis for the construction of the physical map of chromosome $11 \mathrm{p} 13 / \mathrm{p} 14$, was 

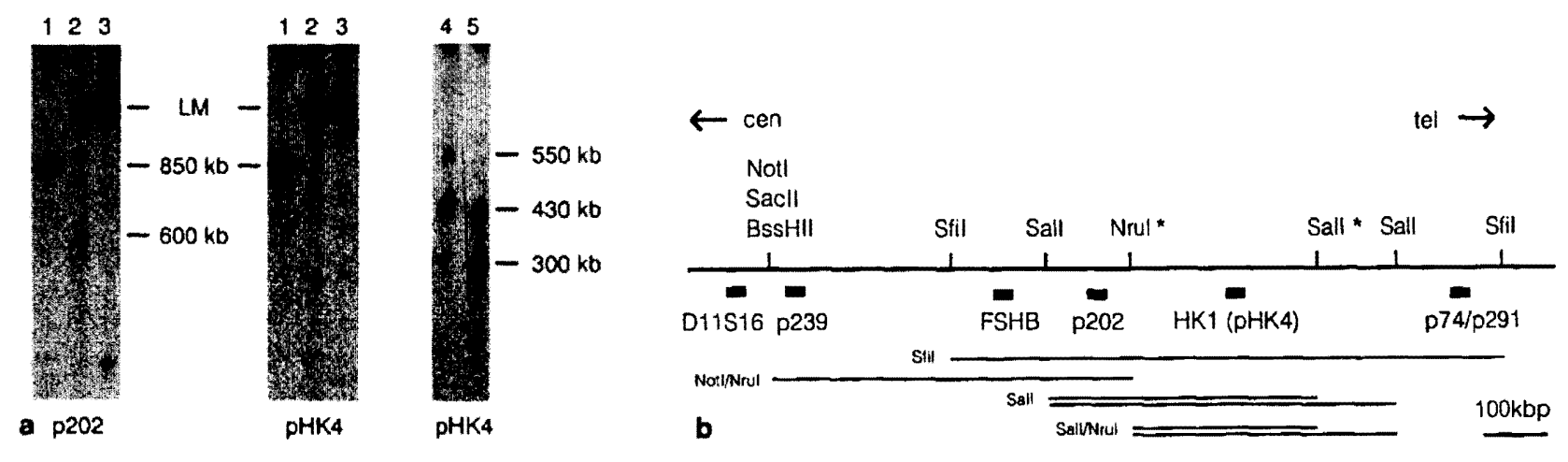

Fig. 1a. PFGE mapping of HK1. Probes pHK4 and p202 hybridize to a common $850-\mathrm{kb}$ Sfil fragment (lane 1). Whereas $\mathrm{p} 202$ recognizes a $600-\mathrm{kb}$ NruUNotl fragment (lane 2), pHK4 only shows hybridization in the limiting mobility region $(L M)$ above $1 \mathrm{Mb}$. The NruI site, which is only partially cut in $6697 \mathrm{DNA}$, thus separates p202 and pHK4. Neither NruI alone (lane 3) nor Not (not shown) produce fragments resolvable under the electrophoretic conditions used. The NruI cutting site can be used to position the $\mathrm{HK}$ l gene more precisely. Sall restriction fragments of $430 \mathrm{~kb}$ and $550 \mathrm{~kb}$ (lane 4), shared with $\mathrm{p} 202$, are shortened by double digestion with $\mathrm{Nrul}$ to $300 \mathrm{~kb}$ and $420 \mathrm{~kb}$. respectively (lane 5). Probe p202 on the other hand recognizes a much smaller Sall/Nrul fragment of approximately $130 \mathrm{~kb}$ (not shown). The double bands probably represent methylation differences. b Schematic drawing representing the mapping of HK1 within $200-600 \mathrm{kbp}$ of FSHB. Sites that are incompletely cut are marked by asterisks. There are several additional Sall sites on both sides of the p202/pHK 4 region that are not shown. The hybridization fragments seen in a are drawn as horizontal lines

used for PFGE analysis. All procedures were carried out essentially as described in Gessler et al. (1989b). In brief, cells were embedded in LMP (low melting point) agarose blocks and used at a final concentration of $2.5 \times 10$ E5 cells per digest with 10-20 units of restriction enzyme. PFGE was carried out in a LKB Pulsaphor unit with the hexagonal electrode array using the following conditions: $170 \mathrm{~V}$, $10-60 \mathrm{~s}$ switching time for $30 \mathrm{~h}$ at $12^{\circ} \mathrm{C}$ for lanes $1-3 \mathrm{in} \mathrm{Fig.} 1 \mathrm{~A}$ and a switching time of $10-40$ for lanes 4 and 5. Blots were prepared by alkaline transfer for $24 \mathrm{~h}$. Size markers used were Saccharomyces cerevisiae chromosomes and phage lambda concatemeres.

\section{Results and discussion}

The sequence of the amplified human DNA fragment (pHK4) is identical to hPCN2 (Nt 527-1207; Philipson et al. 1990), a cDNA from a human skeletal muscle library, except for nucleotides $908 / 909$, which are interchanged in $\mathrm{pHK} 4$, resulting in one amino acid replacement ( $D$ to $\mathrm{S}$, data not shown). On the other hand, the deduced protein sequence of pHK4 is identical to that of HK1 protein (aa177-403; Tamkun et al. 1991), derived from a cDNA library from human ventricle.

To assess the chromosomal localization of the HK1 gene, the 681-bp DNA probe pHK4 was hybridized against a human-rodent somatic cell hybrid panel from 15 chromosomally characterized cell lines. The probe fragment used shows crossreaction with rodent DNA under high stringency hybridization conditions. The human signal, however, could be unambiguously identified based on its size in Sacl- and EcoRI-digested DNA, leading to an initial assignment to chromosome 11 (data not shown).

A subregional mapping was accomplished by using additional human-hamster somatic cell hybrids from the J1 hybrid series (Glaser et al. 1990) together with WAGR deletion hybrids (Gessler et al. 1989a) (Fig. 1a). The human HK1 gene could be detected in hybrid J1-11, retaining 11 pter-11q11 as its only human material. No human-specific signal was detected in hybrids carrying deletions encompassing chromosome 11p13-11p14. The smallest region for $H K 1$ was defined by the WAGR deletion in cell line G157A6 (prox11p14-11p13) (Fig. 1b).

The human chromosome 11 segment deleted in G157A6 has been extensively characterized because of the interest in the genes underlying the WAGR syndrome. The deletion breakpoints for that particular hybrid have been precisely positioned on a long range restriction map spanning the entire region. Thus, the position of any new probe mapping within this area can be directly inferred from is PFGE restriction map.

Initial experiments with probe $\mathrm{pHK} 4$ revealed restriction fragments in the megabasepair range for most rare cutting enzymes; this suggested a localization in the $\mathrm{CpG}$ poor $11 \mathrm{p} 14$ region (Gessler et al. 1989b), but provided little information about its precise position. However, the enzymes $S$ fil revealed the presence of a unique 850 $\mathrm{kb}$ fragment that is also detected by a FSHB probe and several previously characterized DNA markers (Fig. 1). In addition, pHK4 shares Sall fragments of $430 \mathrm{~kb}$ and $550 \mathrm{~kb}$ with probe $\mathrm{p} 202$, from which it is separated by a NruI cutting site. These results unambiguously position HK1 telomeric to probe p202, approximately 200-600 $\mathrm{kb}$ distal to the FSHB gene. As the FSHB gene is located at $11 \mathrm{p} 14$, close to the $11 \mathrm{p} 13 / \mathrm{p} 15$ boundary, the $\mathrm{HK} 1$ gene can thus be assigned to the proximal part of human chromosome $11 \mathrm{p} 14$, namely $11 \mathrm{p} 14.1$.

The genomic HK1 locus is included in a significant fraction of the known WAGR associated cytogenetic deletions, and affected individuals will be hemizygous for this gene. The loci for Wilms tumor/genito-urinary abnormalities and aniridia have been identified recently and both are located proximal to HK1 (Call et al. 1990: Gessler et al. 1989c, 1990; Ton et al. 1991). Only the mental retardation component of the syndrome has not 
yet been unambiguously defined, but again a more centromeric localization appears likely. These data suggests that a hemizygous deletion of HK1 may have little phenotypic effect, perhaps because of less stringent requirements for the control of expression levels for this gene.

Acknowledgement. This work was supported by a grant from the Deutsche Forschungsgemeinschaft (Ge 539/2-2).

\section{References}

Call KM, Glaser T, Ito CY, Buckler AJ, Pelletier J, Haber DA, Rose EA, Kral A, Yeger H, Lewis WH, Jones C, Housman $D E$ (1990) Isolation and characterization of a zinc finger polypeptide gene at the human chromosome 11 Wilm's tumor locus. Cell 60:509-520

Feinberg A, Vogelstein B (1984) A technique for radiolabeling DNA restriction fragments to high specific activity. Addendum Anal Biochem 137:266-267

Gessler M, Thomas GH, Couillin P, Junien C, McGillivary BC, Hayden M, Jaschek G, Bruns GAP (1989a) A deletion map of the WAGR region on chromosome 11. Am J Hum Genet 44: 486-495

Gessler M, Bruns GAP (1989b) A physical map around the WAGR complex on the short arm of chromosome 11 . Genomics $5: 43-55$

Gessler M, Simola KOJ, Bruns GAP (1989c) Cloning of the breakpoints of a chromosome translocation identifies the AN2 locus. Science $224: 1575-1578$

Gessler M, Poustka A, Cavenee W, Neve RL, Orkin SH, Bruns GAP (1990) Homozygous deletion in Wilms tumours of a zincfinger gene identified by chromosome jumping. Nature 343 : 744-778

Glaser TM, Housman DE, Lewis WH, Gerhard DS, Jones C (1990) A fine-structure deletion map of human chromosome 11p: analysis of the J1 series hybrids. Somat Cell Mol Genet $15: 475-490$
Grupe A. Schroeter KH, Ruppersberg JP, Stocker M, Drewes T, Beckh S, Pongs O (1990) Cloning and expression of a human voltage-gated potassium channel. A novel member of the RCK potassium channel family. EMBO J 9:1749-1756

Hille B (1984) Ionic channels of excitable membranes. Sinauer, Sunderland, Mass

Josephson IR, Sanchez-Chapula J, Brown AM (1984) Early outward current in single ventricular cells. Circ Res 54:157-162

Philipson LH, Schaefer K, LaMendola J, Bell GI, Steiner DF (1990) Sequence of a human fetal skeletal muscle potassium channel cDNA related to RCK4. Nucleic Acids Res 18:7160

Sambrook J, Fritsch EF, Maniatis T (1989) Molecular cloning: a laboratory manual, 2nd edn. Cold Sping Harob Laboratory, Cold Spring Harbor, NY

Sanger F, Nicklen S, Coulson AR (1977) DNA sequencing with chain terminating inhibitors. Proc Natl Acad Sci USA 74: 5463-5467

Stuehmer W, Ruppersberg JP, Schröter KH, Sakmann B, Stocker M, Giese KP, Perschke A, Baumann A, Pongs O (1989) Molecular basis of functional diversity of voltage-gated potassium channels in mammalian brain. EMBO J 8:3235-3244

Tamkun MM, Knoth KM, Walbridge JA, Kroemer H, Roden DM, Glover DM (1991) Molecular cloning, and characterization of two voltage-gated $\mathrm{K}+$ channel cDNAs from human ventricle. FASEB J 5:331-337

Ton CCT, Hirvonen H, Miva H, Weil MM, Monaghan P, Jordan $T$, Heyningen V van, Hastie N, Meijers-Heijboer A, Drechsler M, Royer-Pokora B, Collins F, Swaroop A, Strong LC, Saunders GF (1991) Positional cloning and characterization of a paired box- and homeobox-containing gene from the aniridia region. Cell 67: 1059-1074

Watkins PC, Eddy R, Beck AK, Vellucci V, Leverone B, Tanzi RE, Gusella JF, Shows TB (1987) DNA sequence and regional assignment of the follicle-stimulating hormone beta-subunit gene to the short arm of human chromosome 11. DNA 6: 205-212

Willecke K, Jungbluth S, Dahl E, Hennemann H, Heynkes R, Grzeschik K-H (1990) Six genes of the human connexin gene family coding for gap junctional proteins are assigned to four different human chromosomes. Eur J Cell Biol 53:275-280 